\title{
Article \\ Facile Synthesis of N-Doped Graphene Quantum Dots as Novel Transfection Agents for mRNA and pDNA
}

\author{
Minchul Ahn ${ }^{1,2}$, Jaekwang Song ${ }^{1}\left(\mathbb{D}\right.$ and Byung Hee Hong ${ }^{1,3, *}$ \\ 1 Department of Chemistry, College of Natural Sciences, Seoul National University, Seoul 08826, Korea; \\ mincheol@snu.ac.kr (M.A.); saver04@snu.ac.kr (J.S.) \\ 2 BioGraphene Inc., Advanced Institute of Convergence Technology, Suwon 16229, Korea \\ 3 Graphene Research Center, Advanced Institute of Convergence Technology, Suwon 16229, Korea \\ * Correspondence: byunghee@snu.ac.kr
}

check for updates

Citation: Ahn, M.; Song, J.; Hong, B.H. Facile Synthesis of N-Doped Graphene Quantum Dots as Novel Transfection Agents for mRNA and pDNA. Nanomaterials 2021, 11, 2816 https://doi.org/10.3390/

nano11112816

Academic Editor: Cristina Martín

Received: 22 August 2021

Accepted: 13 October 2021

Published: 23 October 2021

Publisher's Note: MDPI stays neutral with regard to jurisdictional claims in published maps and institutional affiliations.

Copyright: (c) 2021 by the authors. Licensee MDPI, Basel, Switzerland. This article is an open access article distributed under the terms and conditions of the Creative Commons Attribution (CC BY) license (https:/ / creativecommons.org/licenses/by/ $4.0 /)$.

\begin{abstract}
In the wake of the coronavirus disease 2019 (COVID-19) pandemic, global pharmaceutical companies have developed vaccines for the severe acute respiratory syndrome coronavirus-2 (SARSCoV-2). Some have adopted lipid nanoparticles (LNPs) or viral vectors to deliver the genes associated with the spike protein of SARS-CoV-2 for vaccination. This strategy of vaccination by delivering genes to express viral proteins has been successfully applied to the mRNA vaccines for COVID-19, and is also applicable to gene therapy. However, conventional transfection agents such as LNPs and viral vectors are not yet sufficient to satisfy the levels of safety, stability, and efficiency required for the clinical applications of gene therapy. In this study, we synthesized N-doped graphene quantum dots (NGQDs) for the transfection of various genes, including messenger ribonucleic acids (mRNAs) and plasmid deoxyribonucleic acids (pDNAs). The positively charged NGQDs successfully formed electrostatic complexes with negatively charged mRNAs and pDNAs, and resulted in the efficient delivery and transfection of the genes into target cells. The transfection efficiency of NGQDs is found to be comparable to that of commercially available LNPs. Considering their outstanding stability even at room temperature as well as their low toxicity, NGQDs are expected to be novel universal gene delivery platforms that can outperform LNPs and viral vectors.
\end{abstract}

Keywords: gene delivery; graphene quantum dots; mRNA; pDNA; transfection

\section{Introduction}

COVID-19, coronavirus disease 2019, has threatened global society, and various types of vaccines have been developed to overcome the pandemic [1-6]. Gene-based vaccines such as messenger ribonucleic acid (mRNA) with lipid nanoparticles (LNPs) or deoxyribonucleic acid (DNA) with viral vectors have been approved by the United States Food and Drug Administration (FDA) for clinical uses [7-11]. Some pharmaceutic companies have developed the vaccine platform based on mRNAs employing LNPs as a delivery platform, which exhibits a high prevention rate [12,13]; others use viral vectors to transfer spike proteins genes into cells, which are similar to Ebola vaccines $[14,15]$. The therapeutic strategy that uses genes such as mRNA or plasmid DNA (pDNA) is called gene therapy, which has drawn much attention because it easily expresses desired proteins in the body through their corresponding sequence information to be transcribed and translated into therapeutic proteins to fight various diseases [16-18].

The viral vectors such as adeno-associated virus (AAV) are the main platforms that deliver genes into cells with high transfection efficiency $[19,20]$. However, they have some drawbacks such as limited size of cavities, high immunogenicity, mutagenesis, and undesired inflammatory responses [21-23]. LNPs, cationic polymers, and inorganic nanoparticles also have been actively recruited as non-viral vectors to overcome such limitations of viral vectors [24]. In particular, LNPs have already been approved by the FDA and have been used to deliver doxorubicin or mRNA $[25,26]$. However, LNPs also 
have drawbacks such as short half-life in the body, harsh storage conditions for stability, and low loading efficiency $[27,28]$. Therefore, it is of great importance to develop alternative gene delivery platforms to overcome the above-mentioned disadvantages.

Many researchers have tried to transfect genes using carbon-based materials such as graphene oxides (GOs) and graphene quantum dots (GQDs) [29-32]. GOs are the oxidized form of graphene sheets with a size ranging from several hundred nanometers to several micrometers [33]. As GOs are soluble in water and can interact with various drugs and genes, they have been utilized as drug delivery and biosensor platforms. It was previously reported that GOs can be modified with polyethylene glycol (PEG), polyethyleneimine (PEI), or/and targeting moieties to deliver genes into a cell [32,34,35]. Although the GO platform shows a good transfection efficiency, their high toxicity has limited their actual in vivo applications.

On the other hand, GQDs with a size of 1 10 nm that are functionalized with hydroxyl, carbonyl, alcohol, carboxylic groups, etc. exhibit relatively low toxicity [36]. This enabled the various applications of GOs in nanomedicine and bio-imaging fields, taking advantages of unique biological, chemical, and optical properties, amphiphilicity, and high biocompatibility [37]. In our previous reports, we found that GQDs with hydrophobic cores and hydrophilic edges interact with $\alpha$-synuclein fibrils and dissociated them into monomers [38]. Additionally, we showed that GQDs exhibit low cytotoxicity and do not affect microbiome environment when fed to mice via oral administration [39]. GQDs also can be loaded with various drug molecules and genes through physicochemical conjugation between their functional groups [40-44]. Like GOs, GQDs need additional functionalization to interact electrostatically or covalently with therapeutic molecules or genes $[45,46]$. However, their relatively complicated synthetic processes has been a hurdle for practical applications $[47,48]$, and the covalent modifications of genes possibly lower the gene activities [49]. In addition, most of previous studies have been focused on the delivery of pDNAs [50-53] as the intracellular distribution of GQDs near the nucleus is supposed to be advantageous for pDNA transfections [54,55]. Recently, Ya et al. reported the first study on the delivery of mRNAs using GQDs [56]. However, in this case, the GQDs required post-modifications with PEI via covalent bonding catalyzed by ethylenediamine (EDA) and dicyclohexycarbodiimide (DCC), which resulted in lower transfection efficiency than that of LNPs. In addition, the PEI-modified GQDs were incapable of delivering other types of genes such as pDNA.

GQD is a promising drug delivery platform that can deliver a wide range of small molecules, peptides, and genes into cells. It was found that GQDs localize in the late endosome or the lysosomes around the Golgi apparatus and nucleus after incubating cells with GQDs, which indicated that the cellular uptake of GQDs happens via endocytosis [55,57-59]. Furthermore, GQDs entered cells through diverse pathways related to endocytosis like caveolae-mediated endocytosis after drug loading. It is well known that GQDs interact with various types of drug molecules like doxorubicin and curcumin through electrostatic interaction or $\pi-\pi$ interaction, where the loaded drugs don't affect cellular uptake efficiency $[42,60,61]$.

Herein, we synthesized positively charged NGQDs as gene transfection agents, utilizing the microwave-assisted hydrothermal reactions between polyethyleneimine (PEI) and citric acid precursors. It was expected that the negatively charged mRNA and pDNA interact electrostatically with the positively charged NGQDs. Indeed, NGQDs showed an excellent transfection efficiency even at 200 times lower concentrations than their CC50 ( $50 \%$ of cytotoxic concentration $\sim 125 \mu \mathrm{g} / \mathrm{mL}$ ). To the best of our knowledge, these are the first applications of the as-synthesized NGQDs capable of transfecting both mRNA and pDNA without additional chemical modifications, which is expected to enable the cost-efficient large-scale synthesis that is essential for future clinical applications. 


\section{Materials and Methods}

\subsection{Synthesis of NGQDS}

$200 \mathrm{mg}$ of citric acid (Sigma Aldrich, St. Louis, MO, USA) and $50 \mathrm{mg}$ of PEI (branched, Mw 1800, Polyscience, Warrington, UK) were added to $15 \mathrm{~mL}$ of distilled water. After 30 min of sonication, a transparent solution was placed into the center of a microwave (MWO2027, 800 W, Midea, Foshan, China). 30 s of a microwave-assisted hydrothermal reaction was iterated about 10 times until the reaction solution turned yellow. The product solution was filtered with $200 \mathrm{~nm}$ and $20 \mathrm{~nm}$ disc filters (Anodisc ${ }^{\mathrm{TM}}$, GE Healthcare Life Sciences, Chicago, IL, USA) and dialyzed for 5 days with a $3.5 \mathrm{kDa}$ dialysis tube (Snakeskin ${ }^{\mathrm{TM}}$, Thermo Fisher Scientific, Waltham, MA, USA) for removal of the remaining reactants. The finished solution was lyophilized for 2 days.

\subsection{Characterization of NGQDS}

The morphology and size distributions of NGQDs were analyzed with a Cs-corrected transmission electron microscope (Cs-TEM; JEM-ARM200F, JEOL Ltd., Tokyo, Japan). The zeta potential was measured by a zeta potential analyzer (Zetasizer NanoS, Malvern Instruments, Malvern, UK). The functional groups of NGQDs were characterized by Fourier transform infrared (FT-IR; Vertex-80V, BRUKER, Billerica, MA, USA) and X-ray photoelectron spectroscopy (XPS; AXIS-His, Kratos Analytical Ltd., Manchester, UK). A Raman spectrometer (in Via Raman microscope, Renishaw, Wotton-under-Edge, UK) was used to identify the D and G bands of the graphene in the NGQDs. The absorbance of the NGQDs was analyzed with an ultraviolet-visible (UV-Vis) spectrophotometer (S3100, Scinco, Seoul, Korea). The emission spectra at various excitation wavelengths were acquired with a spectrofluorometer (FP-8300, Jasco Inc., Tokyo, Japan).

\subsection{Loading Capacity}

To analyze the ratio of NGQDs to genes, 100 ng of mRNA (CleanCap ${ }^{\circledR}$ EGFP mRNA, TriLink Biotechnologies, San Diego, CA, USA) and pDNA (pcDNA3-EGFP, Addgene, Watertown, MA, USA), encoding green fluorescent protein (GFP), were added to various amounts $(0,0.5,1,2,4 \mu \mathrm{g})$ of NGQDs in $20 \mu \mathrm{L}$ of $1 \times$ phosphate buffer saline (PBS) solution. The loading process was executed in a $1 \mathrm{~mL}$ tube. After $1 \mathrm{~h}$ of incubation, the series of complexes were mixed with $4 \mu \mathrm{L}$ of LoadingSTAR ${ }^{\mathrm{TM}}$ (Dyne Bio Inc., Seongnam, Korea) and the mixtures were loaded on a $1 \%$ agarose gel. The loading capacity of NGQDs was determined by measuring the intensity of the bands derived from the remaining genes after agarose-gel electrophoresis (Mupid-2plus, ADVANCE, Tokyo, Japan) at $100 \mathrm{~V}$ for $30 \mathrm{~min}$.

\subsection{Cell Viability Assay}

HeLa cells were seeded in a 96-well plate at a density of $5 \times 10^{3}$ cells for $24 \mathrm{~h}$ before transfection. HeLa cells were then treated with various concentrations of NGQDs in complete media for $24 \mathrm{~h}$. After removal of the media, the cells were washed with $1 \times$ PBS solutions and incubated in $90 \mu \mathrm{L}$ of serum-free media with $10 \mu \mathrm{L}$ of cell counting kit-8 (CCK-8) (Dojindo Molecular Technologies Inc., Rockville, MD, USA) solution. To evaluate the cell viability of the treated cells, the optical density of formazan salt was measured at $450 \mathrm{~nm}$ using a microplate absorbance reader (Synergy Mx, BioTek, Winooski, VT, USA), and the background absorbance of the media was subtracted. Experiments were carried out in triplicate.

\subsection{Gene Transfections Efficiency}

HeLa cells were seeded in a 24-well plate at a density of $3 \times 10^{4}$ cells. After incubation for $24 \mathrm{~h}$, the cells were treated with $1 \times$ PBS (Ctrl), mRNA, Lipofectamine ${ }^{\circledR}$ 2000 (Thermo Fisher Scientific), NGQDs, mRNA with Lipofectamine ${ }^{\circledR}$ 2000, and mRNA with NGQDs in $0.5 \mathrm{~mL}$ of serum-free media. For preparation of the complex-containing genes and the NGQDs, $3 \mu \mathrm{L}$ of mRNA solution $(10 \mu \mathrm{g} / \mathrm{mL})$ and $6 \mu \mathrm{L}$ of NGQDs solution $(0.1 \mathrm{mg} / \mathrm{mL})$ were mixed and $2 \mu \mathrm{L}$ of $10 \times$ PBS solution was added with $9 \mu \mathrm{L}$ of deionized 
water. After incubation with the complexes for $24 \mathrm{~h}$, media were eliminated, and the cells were washed with $1 \mathrm{~mL}$ of $1 \times$ PBS solution. Bright-field and fluorescence images $\left(\lambda_{\mathrm{Ex}} / \lambda_{\mathrm{Em}}=488 \mathrm{~nm} / 507 \mathrm{~nm}\right)$ were acquired by fluorescence microscopy (Nikon Co., Tokyo, Japan) with Metamorph image analysis software (Molecular Devices, San Jose, CA, USA). For quantitative analysis of the transfection, cells were trypsinized and harvested, followed by suspension of the cells in $0.5 \mathrm{~mL}$ of $1 \times$ PBS solution. The fluorescence intensity of the samples was analyzed by flow cytometry (BD FACSLyric, BD Biosciences, New York, NY, USA).

\section{Results and Discussion}

PEI and citric acid were recruited as precursors and GQDs were synthesized by the microwave-assisted hydrothermal reaction. The synthesized GQDs were named Ndoped GQDs (NGQDs). TEM observation of prepared NGQDs was performed to analyze their morphology and size. The NGQDs were identified as nanoparticles with an overall diameter distribution of 3-11 nm and average of $7.03 \mathrm{~nm} \pm 0.27 \mathrm{~nm}$ (Figure $1 \mathrm{a}, \mathrm{b}$ ). The zeta potential is measured to be $1.91 \pm 1.77 \mathrm{mV}$, indicating that the surface charge of NGQDs in deionized water is considerably positive (Figure 1c), which allows NGQDs to interact electrostatically with genes that are negatively charged due to phosphate backbones.

a)

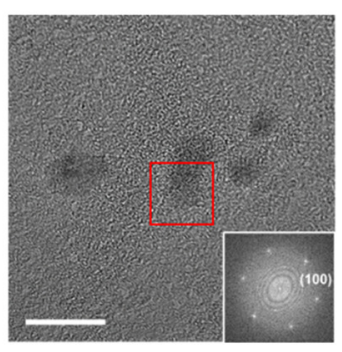

b)

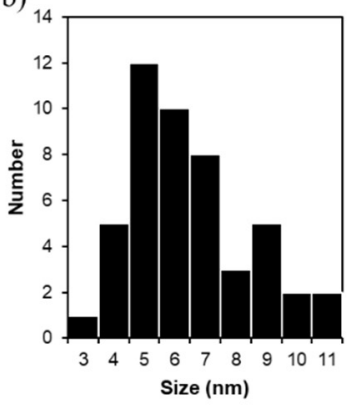

c)

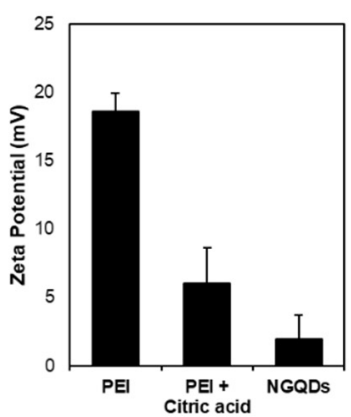

Figure 1. (a) TEM images of NGQDs (scale bar = $20 \mathrm{~nm}$ ). (b) Size distribution of NGQDs. (c) zeta potentials of PEI, PEI + citric acid and NGQDs.

We performed FT-IR and XPS for the analysis of functional groups. We observed the representative peaks of the NGQDs at 1720 and $1650 \mathrm{~cm}^{-1}$, which were interpreted as the $\mathrm{C}=\mathrm{O}$ stretching and $\mathrm{C}=\mathrm{C}$ stretching vibrations in carboxylic acid and aromatic groups, respectively (Figure 2a). In addition, we could clearly observe the peaks at 1550 and $1000-1250 \mathrm{~cm}^{-1}$, which correlated with N-H bending in primary and secondary amine groups as well as the C-N bond of amine groups, and appeared in the FT-IR spectra of the precursors (Figure S1). In XPS C1s and N1s spectra, we found that NGQDs contain aromatic sp2 C=C, sp2 C-N, sp3 C-N, and carboxyl groups, which correspond to the peaks at 284.5, 285.7, 287.5, and $288.6 \mathrm{eV}$ (Figure 2b,c). We also observed the D band and the $\mathrm{G}$ band at $1350 \mathrm{~cm}^{-1}$ and $1580 \mathrm{~cm}^{-1}$, respectively, as the characteristic peaks of graphene from the Raman spectrum (Figure 2d). These results indicate that the NGQDs are composed of hydrophobic aromatic $\mathrm{sp}^{2}$ domains and hydrophilic functional groups such as carboxylic acid, amine groups, etc.

NGQDs show UV-Vis absorption peaks at 250 and $350 \mathrm{~nm}$, which corresponded to the $\pi-\pi^{*}$ transition of aromatic sp2 C=C and the $n-\pi^{*}$ transition of carbonyl C=O [62], respectively, which means that NGQDs are composed of aromatic sp2 $\mathrm{C}=\mathrm{C}$ domains and carbonyl groups (Figure 3a). In addition, the NGQDs emitted blue fluorescence $\left(E_{\mathrm{m}, \max }=432 \mathrm{~nm}\right)$ at $365 \mathrm{~nm}$ excitation (Figure $\left.3 \mathrm{~b}, \mathrm{c}\right)$. From the overall characterization data, we demonstrated that NGQDs had the characteristic properties of GQDs: the graphitic core with the diverse functional groups and the positive charge required to interact with genes. 
a)

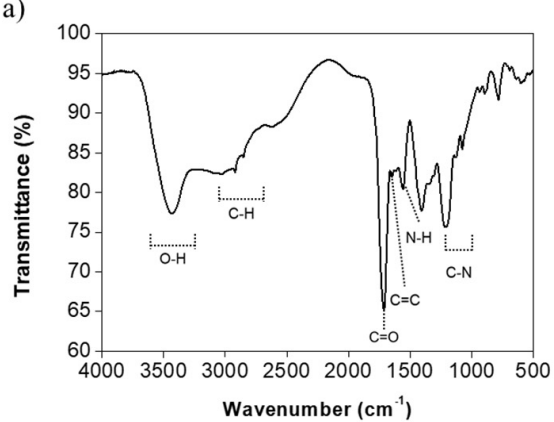

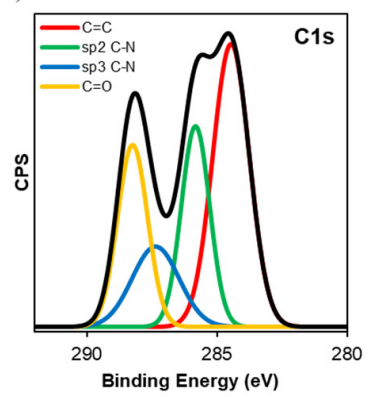

c)

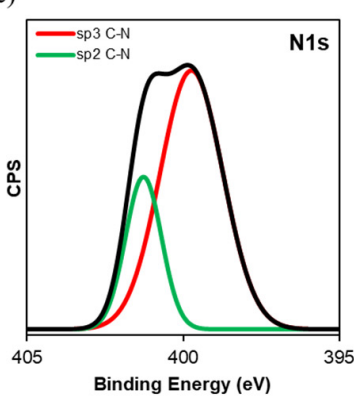

d)

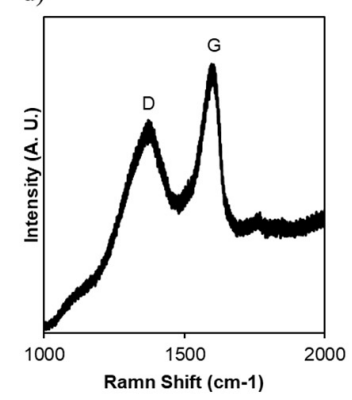

Figure 2. (a) FT-IR spectrum, (b,c) XPS spectra (C1s, N1s), and (d) Raman spectrum of NGQDs.

a)

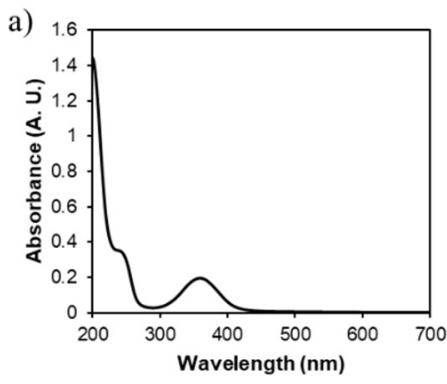

b)

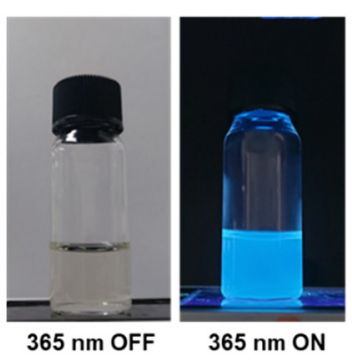

c)

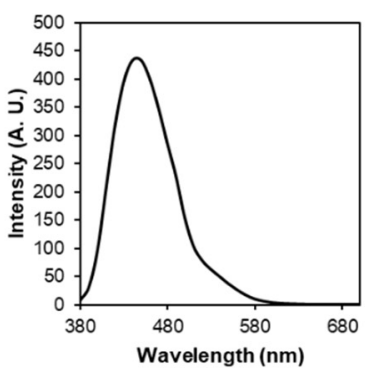

Figure 3. (a) UV-visible absorption spectrum, (b) optical and fluorescence $\left(\lambda_{\mathrm{Ex}}=365 \mathrm{~nm}\right.$ ) images, and (c) emission spectrum of NGQDs $\left(\lambda_{\mathrm{Ex}}=360 \mathrm{~nm}\right)$.

Next, we performed loading tests to evaluate the loading capacity of NGQDs to genes. We mixed the NGQDs with two types of genes in $1 \times$ PBS solutions and incubated them at room temperature. According to the results from the agarose-gel electrophoresis, the columns for $1 \mu \mathrm{g}$ and $0.5 \mu \mathrm{g}$ NGQD, with respect to $0.1 \mu \mathrm{g}$ mRNA and $0.1 \mu \mathrm{g}$ pDNA in agarose gel, show an incomplete band shift. Thus, we supposed that the equivalent amount of NGQDs for perfect loading would be somewhere between 1 and $2 \mu \mathrm{g}$ for $0.1 \mu \mathrm{g}$ mRN, and 0.5 and $1 \mu \mathrm{g}$ for $0.1 \mu \mathrm{g}$ pDNA, respectively (Figure $4 \mathrm{a}, \mathrm{b}$ ). The positively charged NGQDs could interact with genes via electrostatic force and formed complexes with the genes by the simple mixing at room temperature.

a)
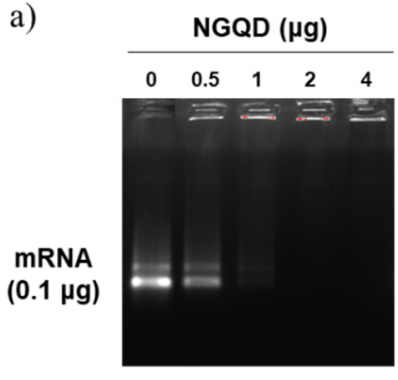

b)

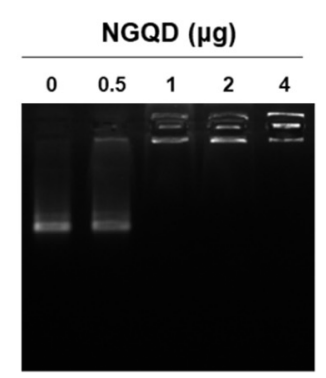

c)

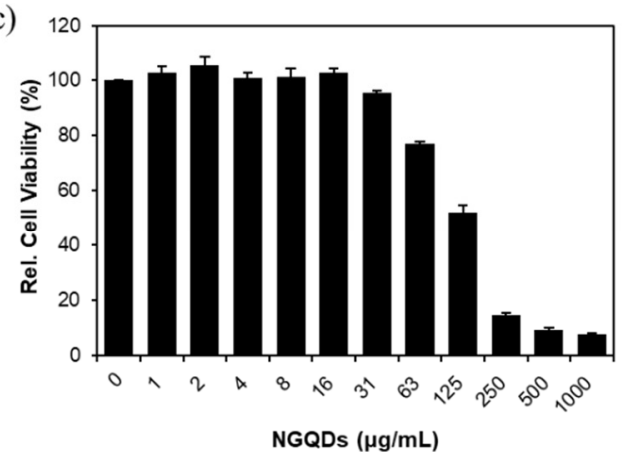

Figure 4. Loading capacity of NGQDs to (a) mRNA and (b) pDNA. (c) Relative cell viability of NGQDs.

Prior to in vitro gene transfection with NGQDs, we verified the cytotoxicity of the NGQDs via a CCK-8 assay kit. For the CCK-8 assay, various concentrations of NGQDs from $1 \mu \mathrm{g} / \mathrm{mL}$ to $1000 \mu \mathrm{g} / \mathrm{mL}$ were treated to HeLa cells in complete media for 1 day. NGQDs exhibited a dose-dependent toxicity, and reduced cell viability was observed at a concentration of $63 \mu \mathrm{g} / \mathrm{mL}$ (Figure $4 \mathrm{c}$ ).

To evaluate the transfection efficiency of NGQDs, we delivered mRNA into HeLa cells with NGQDs. As shown in Figure 4a, the NGQDs formed complexes with mRNA at a 20:1 
ratio (wt/wt), and the results show that $30 \mathrm{ng}$ of mRNA, encoding a GFP, formed complexes with $600 \mathrm{ng}$ of NGQDs before transfection. As a positive control, Lipofectamine 2000 was used, a representative transfection agent that forms liposomes with various genes. After incubation for $1 \mathrm{~h}$ at room temperature, the NGQDs + mRNA complexes, as well as other groups- $1 \times$ PBS (control), mRNA only, Lipofectamine only, NGQDs only, Lipofectamine + mRNA-were treated to HeLa cells for $24 \mathrm{~h}$. To visually confirm the transfection by each group, we observed green fluorescence through fluorescence microscopy. The fluorescence images from Figure 5 show that the number of cells expressing GFP in the NGQDs + mRNA complex group was comparable to groups using Lipofectamine as a transfection agent (Figure 5e,f). These results indicate that the NGQDs with gene complexes had entered the cell successfully. This result shows that the NGQDs formed complexes with mRNA and pDNA at 10-20 times their amounts, which implies that several NGQDs wrap an mRNA or DNA molecule and deliver it to nearby cellular membranes, followed by cellular uptake. We supposed that the neutralized charge complex between NGQDs and genes enables cellular uptake, although some have previously reported the preferred interaction of the positively charged NGQDs with the cellular membrane [63-65]. Although the NGQDs had fluorescence emission at around $500 \mathrm{~nm}$ under excitation at $360 \mathrm{~nm}$, a similar wavelength to GFP emission, the fluorescence in Figure $5 \mathrm{f}$ did not result from NGQD fluorescence. The fluorescence of NGQDs was not visualized in fluorescence microscope images because the excitation range of NGQDs is from 280 to $430 \mathrm{~nm}$, and not the GFP excitation wavelength $(\sim 488 \mathrm{~nm})$ (Figures $5 \mathrm{~d}$ and S2). From these results, we can conclude that NGQDs have been successfully delivered mRNA into cells, followed by translation to generate therapeutic proteins.

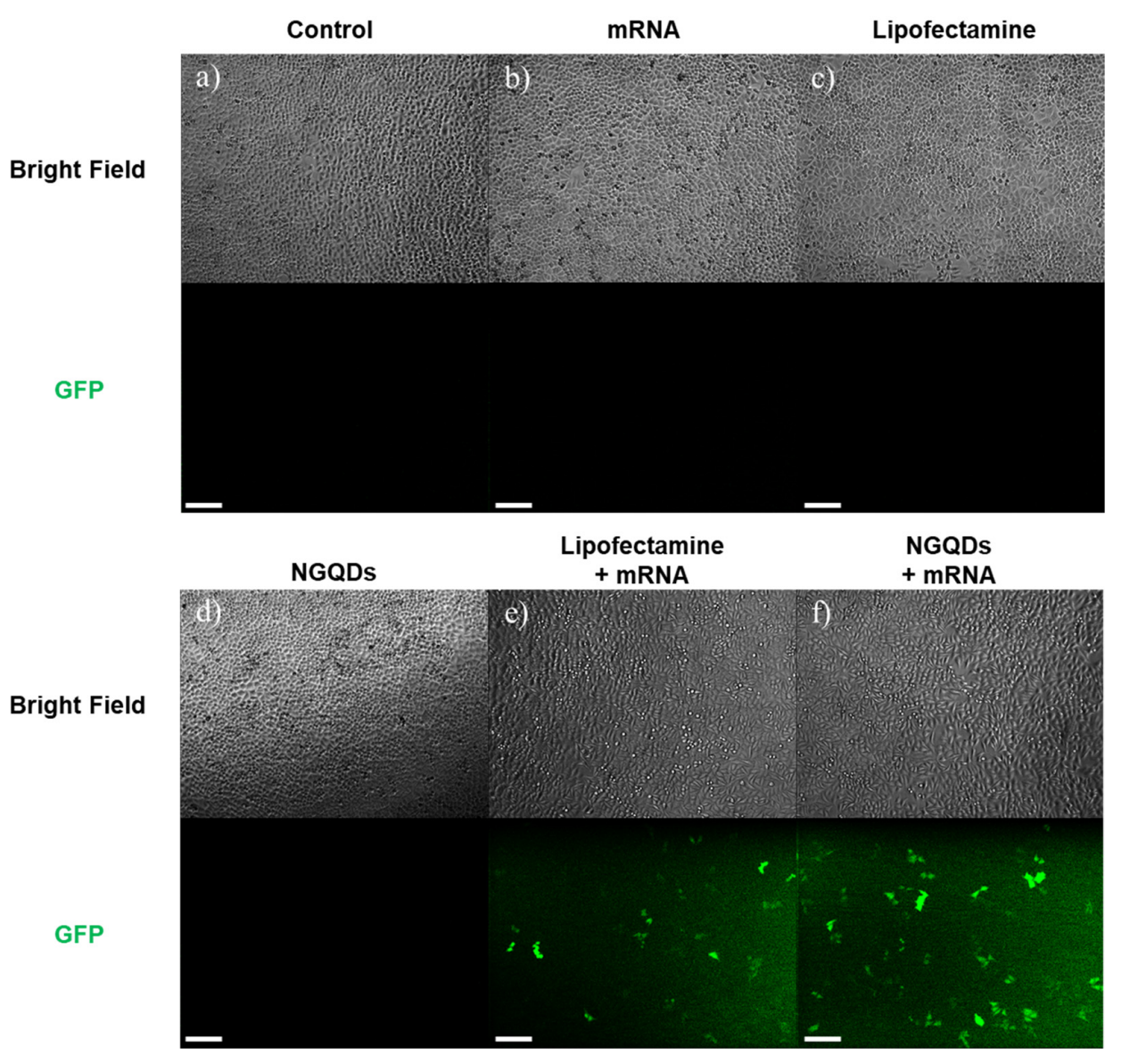

Figure 5. Fluorescence microscopy images of HeLa cells after $24 \mathrm{~h}$ transfection with (a) control (1 $\times$ PBS), (b) mRNA only, (c) Lipofectamine only, (d) NGQDs only, (e) Lipofectamine + mRNA complex, and (f) NGQDs + mRNA complex. All scale bars are $200 \mu \mathrm{m}$. 
We performed a flow cytometry analysis to quantify the transfection efficiencies of each group. Similar to the results of fluorescence microscopy, GFP-expressing cells were not detected in control, mRNA only, Lipofectamine only, and NGQDs only groups. In particular, the fluorescence of NGQDs at around $500 \mathrm{~nm}$ did not affect the flow cytometry analysis. Although both the NGQDs + mRNA complex and the Lipofectamine + mRNA complex had similar fluorescence images, the NGQDs + mRNA complex showed enhanced transfection of up to $50 \%$ when compared to the Lipofectamine + mRNA complex, the positive control in the quantitative analysis (Figures 6 and S3). Through these experiments, NGQDs have great potential as mRNA delivery platforms for vaccinations or gene therapy even though there are a few more factors to be validated, such as in vivo safety and efficiency.

a)

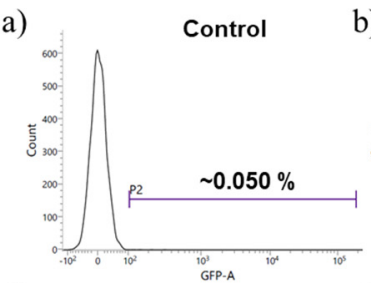

d)

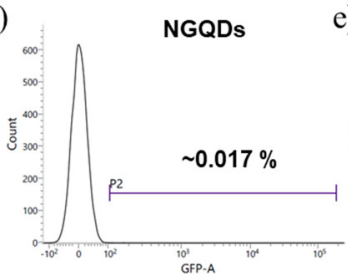

b)

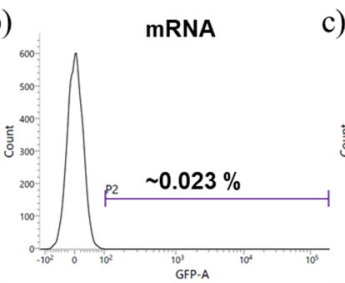

e)

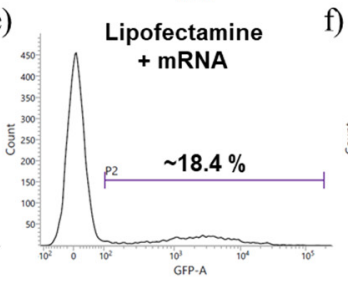

c)

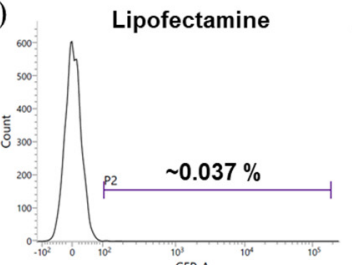

f)

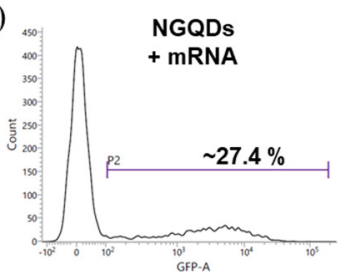

g)

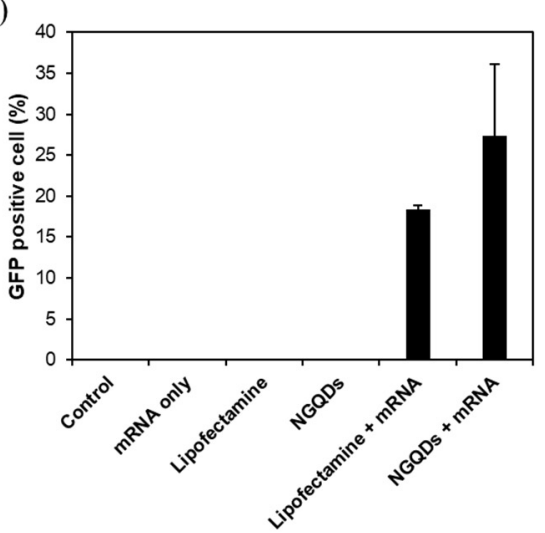

Figure 6. Flow cytometry analysis of HeLa cells after $24 \mathrm{~h}$ transfection with each group; (a) control, (b) mRNA only, (c) Lipofectamine only, (d) NGQDs only, (e) Lipofectamine + mRNA complex, (f) NGQDs + mRNA complex groups. (g) mRNA transfection efficiency of each group.

In addition to mRNA, we performed a pDNA transfection test using NGQDs. similarly, the GFP-encoding pDNA complexed with NGQDs were prepared by simply mixing them at room temperature. After incubation for $1 \mathrm{~h}$, we treated each group to HeLa cells for $24 \mathrm{~h}$. Fluorescence microscopy images after treatments show that NGQDs had the best performance as pDNA delivery platforms. In the fluorescence microscope image, the NGQDs + pDNA group showed the strong green fluorescence comparable to the Lipofectamine + pDNA group (Figure 7).

A flow cytometry analysis was performed to quantify the transfection efficiencies. As a result of the flow cytometry analysis, the transfection efficiency of NGQDs $(\sim 42.5 \%)$ was slightly lower than that of the Lipofectamine + pDNA group ( 49.3\%) (Figure 8 and Figure $\mathrm{S} 4)$. The disagreement between the flow cytometry results in Figure $8 \mathrm{~g}$ and the fluorescence microscopy image in Figure 7e,f is likely due to the difference in the fluorescence intensities of the transfected cells. The cells treated with pDNA + NGQDs tend to express strong fluorescence in flow cytometry analysis, which made the fluorescence image brighter as shown in Figure 7e,f. Despite that mRNA and pDNA work at the different intracellular locations, we confirmed that NGQDs are capable of delivering both genes into the cells, and the transfected genes are functioning, successfully [54]. 


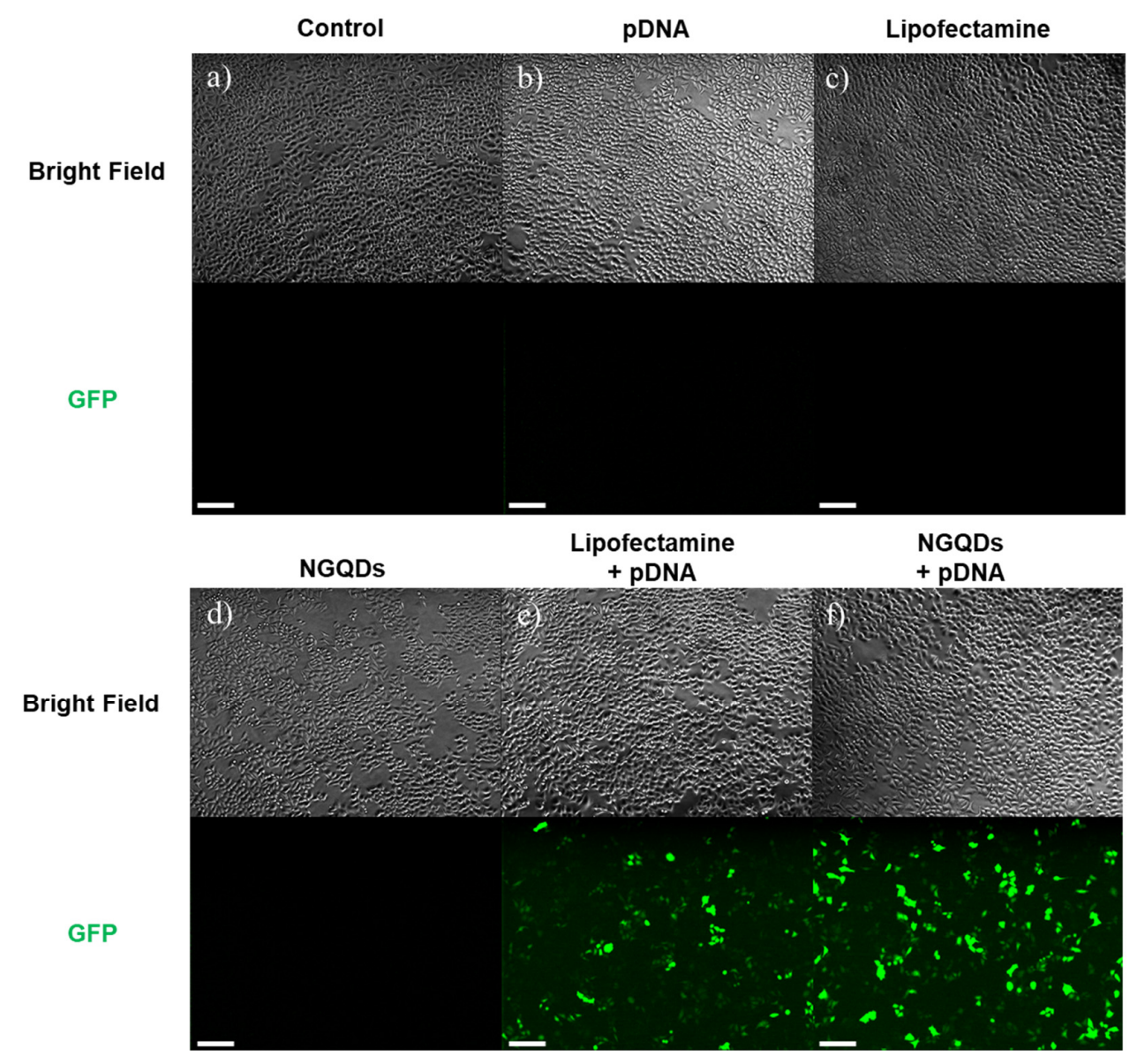

Figure 7. Fluorescence microscopy images of HeLa cells after $24 \mathrm{~h}$ transfection with (a) control, (b) pDNA only, (c) Lipofectamine only, (d) NGQDs only, (e) Lipofectamine + pDNA complex, and (f) NGQDs + pDNA complex. All scale bars are $200 \mu \mathrm{m}$.
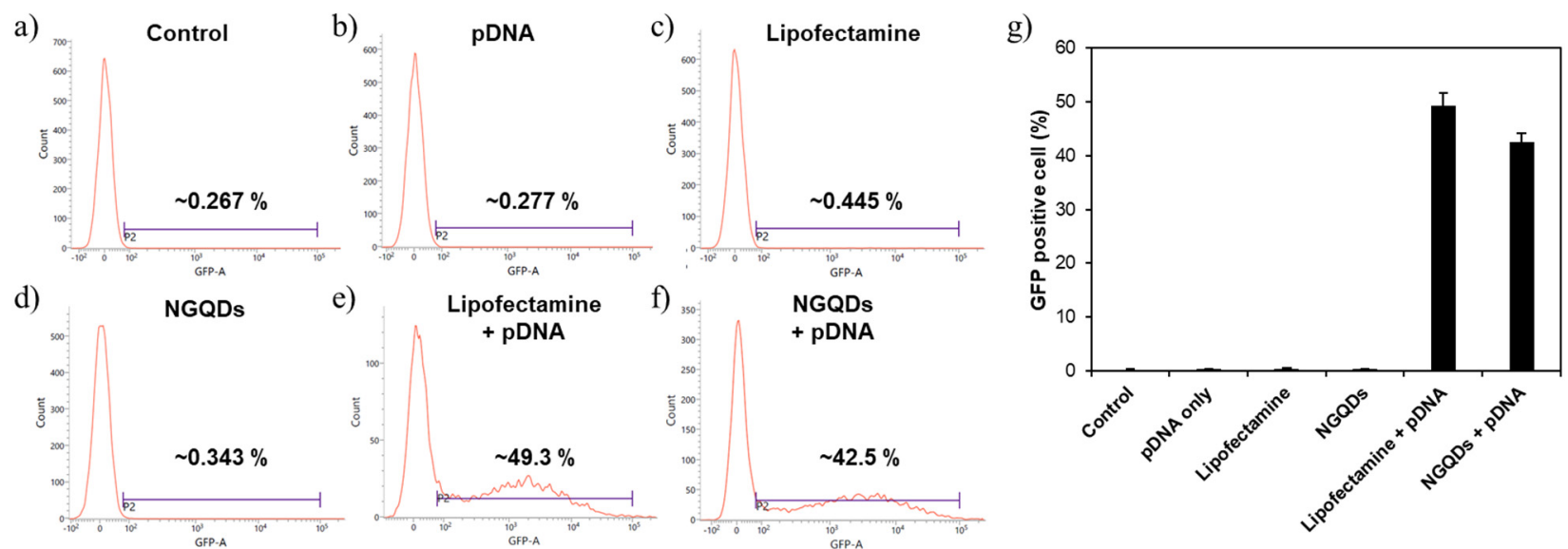

Figure 8. Flow cytometry analysis of HeLa cells after $24 \mathrm{~h}$ transfection with each group; (a) control, (b) pDNA only, (c) Lipofectamine only, (d) NGQDs only, (e) Lipofectamine + pDNA complex, (f) NGQDs + pDNA complex groups. (g) pDNA transfection efficiency of each group.

\section{Conclusions}

In conclusion, we synthesized positively charged NGQDs to deliver genes such as mRNA and pDNA. NGQDs were synthesized using PEI and citric acid as precursors to give positive charges. The NGQDs synthesized via microwave-assisted hydrothermal reactions were characterized by TEM, DLS, FT-IR, XPS, and Raman spectroscopy. Overall 
characterization data exhibit that NGQDs consist of a hydrophobic graphene domain and hydrophilic functional groups such as carboxylic acid and amine. It is confirmed that the positively charged NGQDs interact with the model mRNA and pDNA, the representative types of components for gene therapy, and transfect the cells, successfully. Thegene transfection efficiency of NGQDs was measured to be comparable to Lipofectamine that is recognized as the "gold-standard" for in vitro gene transfection agents. Even in the case of mRNA transfection, the NGQDs exhibited a better performance than Lipofectamine. We expect that NGQDs can be utilized in the clinical field after further studies on their toxicity and metabolism in consideration of the previous studies on the intracellular distribution of NGQDs [55,66].

Supplementary Materials: The following are available online at https: / /www.mdpi.com/article / 10.3390/nano11112816/s1, Figure S1: FT-IR spectra for NGQDs, PEI + citric acid, and PEI. Figure S2: Emission spectra of NGQDs at excitation wavelength from $280 \mathrm{~nm}$ to $580 \mathrm{~nm}$. Figure S3: Flow cytometry analysis for mRNA transfection efficiency. Figure S4: Flow cytometry analysis for pDNA transfection efficiency.

Author Contributions: Conceptualization, B.H.H. and M.A.; methodology, B.H.H. and M.A.; formal analysis, M.A., J.S.; investigation, M.A., J.S.; writing—original draft preparation, M.A., J.S., B.H.H.; supervision, B.H.H.; project administration, B.H.H.; All authors have read and agreed to the published version of the manuscript.

Funding: This research was funded by BioGraphene Inc. (0581-2021-0027).

Institutional Review Board Statement: Not applicable.

Informed Consent Statement: Not applicable.

Data Availability Statement: The data presented in this study are available on request from the corresponding author.

Conflicts of Interest: The authors declare no conflict of interest.

\section{References}

1. Knoll, M.D.; Wonodi, C. Oxford-AstraZeneca COVID-19 vaccine efficacy. Lancet 2021, 397, 72-74. [CrossRef]

2. Polack, F.P.; Thomas, S.J.; Kitchin, N.; Absalon, J.; Gurtman, A.; Lockhart, S.; Perez, J.L.; Pérez Marc, G.; Moreira, E.D.; Zerbini, C.; et al. Safety and Efficacy of the BNT162b2 mRNA COVID-19 Vaccine. N. Engl. J. Med. 2020, 383, 2603-2615. [CrossRef]

3. Graham, B.S. Rapid COVID-19 vaccine development. Science 2020, 368, 945-946. [CrossRef] [PubMed]

4. Thanh Le, T.; Andreadakis, Z.; Kumar, A.; Gomez Roman, R.; Tollefsen, S.; Saville, M.; Mayhew, S. The COVID-19 vaccine development landscape. Nat. Rev. Drug Discov. 2020, 19, 305-306. [CrossRef]

5. Corey, L.; Mascola, J.R.; Fauci, A.S.; Collins, F.S. A strategic approach to COVID-19 vaccine R\&D. Science 2020, 368, 948-950. [CrossRef]

6. Lee, N.; McGeer, A. The starting line for COVID-19 vaccine development. Lancet 2020, 395, 1815-1816. [CrossRef]

7. Jeyanathan, M.; Afkhami, S.; Smaill, F.; Miller, M.S.; Lichty, B.D.; Xing, Z. Immunological considerations for COVID-19 vaccine strategies. Nat. Rev. Immunol. 2020, 20, 615-632. [CrossRef]

8. Abu-Raddad, L.J.; Chemaitelly, H.; Butt, A.A. Effectiveness of the BNT162b2 COVID-19 Vaccine against the B.1.1.7 and B.1.351 Variants. N. Engl. J. Med. 2021, 385, 187-189. [CrossRef]

9. Chung, Y.H.; Beiss, V.; Fiering, S.N.; Steinmetz, N.F. COVID-19 Vaccine Frontrunners and Their Nanotechnology Design. ACS Nano 2020, 14, 12522-12537. [CrossRef]

10. Mellet, J.; Pepper, M.S. A COVID-19 Vaccine: Big Strides Come with Big Challenges. Vaccines 2021, 9, 39. [CrossRef]

11. Haque, A.; Pant, A.B. Efforts at COVID-19 Vaccine Development: Challenges and Successes. Vaccines 2020, 8, 739. [CrossRef] [PubMed]

12. Benenson, S.; Oster, Y.; Cohen, M.J.; Nir-Paz, R. BNT162b2 mRNA COVID-19 Vaccine Effectiveness among Health Care Workers. N. Engl. J. Med. 2021, 384, 1775-1777. [CrossRef] [PubMed]

13. Walsh, E.E.; Frenck, R.W.; Falsey, A.R.; Kitchin, N.; Absalon, J.; Gurtman, A.; Lockhart, S.; Neuzil, K.; Mulligan, M.J.; Bailey, R.; et al. Safety and Immunogenicity of Two RNA-Based COVID-19 Vaccine Candidates. N. Engl. J. Med. 2020, 383, 2439-2450. [CrossRef]

14. Madhi, S.A.; Baillie, V.; Cutland, C.L.; Voysey, M.; Koen, A.L.; Fairlie, L.; Padayachee, S.D.; Dheda, K.; Barnabas, S.L.; Bhorat, Q.E.; et al. Efficacy of the ChAdOx1 nCoV-19 COVID-19 Vaccine against the B.1.351 Variant. N. Engl. J. Med. 2021, 384, 1885-1898. [CrossRef] 
15. Hung, I.F.N.; Poland, G.A. Single-dose Oxford-AstraZeneca COVID-19 vaccine followed by a 12-week booster. Lancet 2021, 397, 854-855. [CrossRef]

16. Wirth, T.; Parker, N.; Ylä-Herttuala, S. History of gene therapy. Gene 2013, 525, 162-169. [CrossRef]

17. Dunbar, C.E.; High, K.A.; Joung, J.K.; Kohn, D.B.; Ozawa, K.; Sadelain, M. Gene therapy comes of age. Science 2018, 359 , eaan4672. [CrossRef] [PubMed]

18. Weissman, D.; Karikó, K. mRNA: Fulfilling the Promise of Gene Therapy. Mol. Ther. 2015, 23, 1416-1417. [CrossRef]

19. Sheridan, C. Gene therapy finds its niche. Nat. Biotechnol. 2011, 29, 121-128. [CrossRef]

20. Deverman, B.E.; Ravina, B.M.; Bankiewicz, K.S.; Paul, S.M.; Sah, D.W.Y. Gene therapy for neurological disorders: Progress and prospects. Nat. Rev. Drug Discov. 2018, 17, 641-659. [CrossRef]

21. Mulligan, R. The basic science of gene therapy. Science 1993, 260, 926-932. [CrossRef]

22. Somia, N.; Verma, I.M. Gene therapy: Trials and tribulations. Nat. Rev. Genet. 2000, 1, 91-99. [CrossRef]

23. Naldini, L. Gene therapy returns to centre stage. Nature 2015, 526, 351-360. [CrossRef] [PubMed]

24. Del Pozo-Rodríguez, A.; Solinís, M.Á.; Rodríguez-Gascón, A. Applications of lipid nanoparticles in gene therapy. Eur. J. Pharm. Biopharm. 2016, 109, 184-193. [CrossRef]

25. Barenholz, Y. Doxil®_-The first FDA-approved nano-drug: Lessons learned. J. Control. Release 2012, 160, 117-134. [CrossRef]

26. Tenchov, R.; Bird, R.; Curtze, A.E.; Zhou, Q. Lipid Nanoparticles-From Liposomes to mRNA Vaccine Delivery, a Landscape of Research Diversity and Advancement. ACS Nano 2021. [CrossRef] [PubMed]

27. Kim, J.H.; Marks, F.; Clemens, J.D. Looking beyond COVID-19 vaccine phase 3 trials. Nat. Med. 2021, 27, 205-211. [CrossRef] [PubMed]

28. Gustafsson, J.; Arvidson, G.; Karlsson, G.; Almgren, M. Complexes between cationic liposomes and DNA visualized by cryo-TEM. Biochim. Biophys. Acta Biomembr. 1995, 1235, 305-312. [CrossRef]

29. Imani, R.; Mohabatpour, F.; Mostafavi, F. Graphene-based Nano-Carrier modifications for gene delivery applications. Carbon 2018, 140, 569-591. [CrossRef]

30. Yoo, J.M.; Kang, J.H.; Hong, B.H. Graphene-based nanomaterials for versatile imaging studies. Chem. Soc. Rev. 2015, 44, 4835-4852. [CrossRef] [PubMed]

31. Bao, H.; Pan, Y.; Ping, Y.; Sahoo, N.G.; Wu, T.; Li, L.; Li, J.; Gan, L.H. Chitosan-Functionalized Graphene Oxide as a Nanocarrier for Drug and Gene Delivery. Small 2011, 7, 1569-1578. [CrossRef] [PubMed]

32. Feng, L.; Yang, X.; Shi, X.; Tan, X.; Peng, R.; Wang, J.; Liu, Z. Polyethylene Glycol and Polyethylenimine Dual-Functionalized Nano-Graphene Oxide for Photothermally Enhanced Gene Delivery. Small 2013, 9, 1989-1997. [CrossRef] [PubMed]

33. Dideikin, A.T.; Vul', A.Y. Graphene Oxide and Derivatives: The Place in Graphene Family. Front. Phys. 2019, 6, 149. [CrossRef]

34. Yin, F.; Hu, K.; Chen, Y.; Yu, M.; Wang, D.; Wang, Q.; Yong, K.-T.; Lu, F.; Liang, Y.; Li, Z. SiRNA Delivery with PEGylated Graphene Oxide Nanosheets for Combined Photothermal and Genetherapy for Pancreatic Cancer. Theranostics 2017, 7, 1133-1148. [CrossRef]

35. Kim, H.; Namgung, R.; Singha, K.; Oh, I.-K.; Kim, W.J. Graphene Oxide-Polyethylenimine Nanoconstruct as a Gene Delivery Vector and Bioimaging Tool. Bioconjug. Chem. 2011, 22, 2558-2567. [CrossRef]

36. Peng, J.; Gao, W.; Gupta, B.K.; Liu, Z.; Romero-Aburto, R.; Ge, L.; Song, L.; Alemany, L.B.; Zhan, X.; Gao, G.; et al. Graphene Quantum Dots Derived from Carbon Fibers. Nano Lett. 2012, 12, 844-849. [CrossRef]

37. Tian, P.; Tang, L.; Teng, K.S.; Lau, S.P. Graphene quantum dots from chemistry to applications. Mater. Today Chem. 2018, 10, 221-258. [CrossRef]

38. Kim, D.; Yoo, J.M.; Hwang, H.; Lee, J.; Lee, S.H.; Yun, S.P.; Park, M.J.; Lee, M.; Choi, S.; Kwon, S.H.; et al. Graphene quantum dots prevent $\alpha$-synucleinopathy in Parkinson's disease. Nat. Nanotechnol. 2018, 13, 812-818. [CrossRef]

39. Lee, B.-C.; Lee, J.Y.; Kim, J.; Shin, N.; Yoo, J.M.; Kang, I.; Kim, J.-J.; Lee, S.-E.; Kim, D.; Choi, S.W.; et al. Oral administration of microbiome-friendly graphene quantum dots as therapy for colitis. 2D Mater. 2021, 8, 025036. [CrossRef]

40. Chen, H.; Wang, Z.; Zong, S.; Chen, P.; Zhu, D.; Wu, L.; Cui, Y. A graphene quantum dot-based FRET system for nuclear-targeted and real-time monitoring of drug delivery. Nanoscale 2015, 7, 15477-15486. [CrossRef] [PubMed]

41. Iannazzo, D.; Pistone, A.; Salamò, M.; Galvagno, S.; Romeo, R.; Giofré, S.V.; Branca, C.; Visalli, G.; di Pietro, A. Graphene quantum dots for cancer targeted drug delivery. Int. J. Pharm. 2017, 518, 185-192. [CrossRef] [PubMed]

42. Xue, Z.; Sun, Q.; Zhang, L.; Kang, Z.; Liang, L.; Wang, Q.; Shen, J.-W. Graphene quantum dot assisted translocation of drugs into a cell membrane. Nanoscale 2019, 11, 4503-4514. [CrossRef] [PubMed]

43. Ding, H.; Zhang, F.; Zhao, C.; Lv, Y.; Ma, G.; Wei, W.; Tian, Z. Beyond a Carrier: Graphene Quantum Dots as a Probe for Programmatically Monitoring Anti-Cancer Drug Delivery, Release, and Response. ACS Appl. Mater. Interfaces 2017, 9, 2739627401. [CrossRef]

44. Biswas, M.C.; Islam, M.T.; Nandy, P.K.; Hossain, M.M. Graphene Quantum Dots (GQDs) for Bioimaging and Drug Delivery Applications: A Review. ACS Mater. Lett. 2021, 3, 889-911. [CrossRef]

45. Wu, C.; Guan, X.; Xu, J.; Zhang, Y.; Liu, Q.; Tian, Y.; Li, S.; Qin, X.; Yang, H.; Liu, Y. Highly efficient cascading synergy of cancer photo-immunotherapy enabled by engineered graphene quantum dots/photosensitizer/CpG oligonucleotides hybrid nanotheranostics. Biomaterials 2019, 205, 106-119. [CrossRef]

46. Zhao, C.; Song, X.; Liu, Y.; Fu, Y.; Ye, L.; Wang, N.; Wang, F.; Li, L.; Mohammadniaei, M.; Zhang, M.; et al. Synthesis of graphene quantum dots and their applications in drug delivery. J. Nanobiotechnol. 2020, 18, 142. [CrossRef] 
47. Pang, Y.; Gao, H.; Wu, S.; Li, X. Facile synthesis the nitrogen and sulfur co-doped carbon dots for selective fluorescence detection of heavy metal ions. Mater. Lett. 2017, 193, 236-239. [CrossRef]

48. Zhou, Z.-W.; Liu, Y.-T.; Xie, X.-M.; Ye, X.-Y. Aluminothermic reduction enabled synthesis of silicon hollow microspheres from commercialized silica nanoparticles for superior lithium storage. Chem. Commun. 2016, 52, 8401-8404. [CrossRef]

49. Carnerero, J.M.; Jimenez-Ruiz, A.; Castillo, P.M.; Prado-Gotor, R. Covalent and Non-Covalent DNA-Gold-Nanoparticle Interactions: New Avenues of Research. ChemPhysChem 2017, 18, 17-33. [CrossRef]

50. Ghafary, S.M.; Nikkhah, M.; Hatamie, S.; Hosseinkhani, S. Simultaneous Gene Delivery and Tracking through Preparation of Photo-Luminescent Nanoparticles Based on Graphene Quantum Dots and Chimeric Peptides. Sci. Rep. 2017, 7, 9552. [CrossRef]

51. Mohammadinejad, R.; Dadashzadeh, A.; Moghassemi, S.; Ashrafizadeh, M.; Dehshahri, A.; Pardakhty, A.; Sassan, H.; Sohrevardi, S.-M.; Mandegary, A. Shedding light on gene therapy: Carbon dots for the minimally invasive image-guided delivery of plasmids and noncoding RNAs-A review. J. Adv. Res. 2019, 18, 81-93. [CrossRef] [PubMed]

52. Rezaei, A.; Hashemi, E. A pseudohomogeneous nanocarrier based on carbon quantum dots decorated with arginine as an efficient gene delivery vehicle. Sci. Rep. 2021, 11, 13790. [CrossRef]

53. Cao, X.; Wang, J.; Deng, W.; Chen, J.; Wang, Y.; Zhou, J.; Du, P.; Xu, W.; Wang, Q.; Wang, Q.; et al. Photoluminescent Cationic Carbon Dots as efficient Non-Viral Delivery of Plasmid SOX9 and Chondrogenesis of Fibroblasts. Sci. Rep. 2018, 8, 7057. [CrossRef] [PubMed]

54. Gonçalves, C.; Akhter, S.; Pichon, C.; Midoux, P. Intracellular Availability of pDNA and mRNA after Transfection: A Comparative Study among Polyplexes, Lipoplexes, and Lipopolyplexes. Mol. Pharm. 2016, 13, 3153-3163. [CrossRef]

55. Kersting, D.; Fasbender, S.; Pilch, R.; Kurth, J.; Franken, A.; Ludescher, M.; Naskou, J.; Hallenberger, A.; Gall, C.V.; Mohr, C.J.; et al. From in vitro to ex vivo: Subcellular localization and uptake of graphene quantum dots into solid tumors. Nanotechnology 2019, 30, 395101. [CrossRef] [PubMed]

56. Liu, Y.; Zhao, C.; Sabirsh, A.; Ye, L.; Wu, X.; Lu, H.; Liu, J. A Novel Graphene Quantum Dot-Based mRNA Delivery Platform. ChemistryOpen 2021, 10, 666-671. [CrossRef]

57. Wu, C.; Wang, C.; Han, T.; Zhou, X.; Guo, S.; Zhang, J. Insight into the Cellular Internalization and Cytotoxicity of Graphene Quantum Dots. Adv. Healthc. Mater. 2013, 2, 1613-1619. [CrossRef]

58. Chung, S.; Revia, R.A.; Zhang, M. Graphene Quantum Dots and Their Applications in Bioimaging, Biosensing, and Therapy. Adv. Mater. 2021, 33, 1904362. [CrossRef]

59. Shang, W.; Zhang, X.; Zhang, M.; Fan, Z.; Sun, Y.; Han, M.; Fan, L. The uptake mechanism and biocompatibility of graphene quantum dots with human neural stem cells. Nanoscale 2014, 6, 5799-5806. [CrossRef]

60. Wang, C.; Wu, C.; Zhou, X.; Han, T.; Xin, X.; Wu, J.; Zhang, J.; Guo, S. Enhancing Cell Nucleus Accumulation and DNA Cleavage Activity of Anti-Cancer Drug via Graphene Quantum Dots. Sci. Rep. 2013, 3, 2852. [CrossRef] [PubMed]

61. Henna, T.K.; Pramod, K. Graphene quantum dots redefine nanobiomedicine. Mater. Sci. Eng. C 2020, 110, 110651. [CrossRef]

62. Assunção, I.C.C.; Sério, S.; Ferreira, Q.; Jones, N.C.; Hoffmann, S.V.; Ribeiro, P.A.; Raposo, M. Graphene Oxide Layer-by-Layer Films for Sensors and Devices. Nanomaterials 2021, 11, 1556. [CrossRef] [PubMed]

63. Zhang, L.W.; Monteiro-Riviere, N.A. Mechanisms of Quantum Dot Nanoparticle Cellular Uptake. Toxicol. Sci. 2009, 110, 138-155. [CrossRef]

64. Hanada, S.; Fujioka, K.; Inoue, Y.; Kanaya, F.; Manome, Y.; Yamamoto, K. Cell-Based in Vitro Blood-Brain Barrier Model Can Rapidly Evaluate Nanoparticles' Brain Permeability in Association with Particle Size and Surface Modification. Int. J. Mol. Sci. 2014, 15, 1812-1825. [CrossRef]

65. Perini, G.; Palmieri, V.; Ciasca, G.; de Spirito, M.; Papi, M. Unravelling the Potential of Graphene Quantum Dots in Biomedicine and Neuroscience. Int. J. Mol. Sci. 2020, 21, 3712. [CrossRef] [PubMed]

66. Perini, G.; Palmieri, V.; Ciasca, G.; D'Ascenzo, M.; Gervasoni, J.; Primiano, A.; Rinaldi, M.; Fioretti, D.; Prampolini, C.; Tiberio, F.; et al. Graphene Quantum Dots' Surface Chemistry Modulates the Sensitivity of Glioblastoma Cells to Chemotherapeutics. Int. J. Mol. Sci. 2020, 21, 6301. [CrossRef] [PubMed] 